\title{
ĐIỀU TRI VIÊM PHÚC MẠC RUỘT THỪA Ở TRẺ EM BẰNG PHẪU THUẬT NộI SOI MộT TROCAR KHÔNG ĐặT DẪN LƯU
}

\begin{abstract}
Nguyễn Thị Hồng Vân*, Trần Ngọc Sơn*, Phạm Đức Hiệp*
TÓM TẮT

Muc tiêu: Báo cáo kết quả điều tri viêm phúc mạc ruột thừa (VPMRT) ở trẻ em bằng phẫu thuật nội soi một trocar không đặt dẫn lưu (PTNSMTKDL). Phương pháp nghiên cứu: Hồi cứu các trường hợp bệnh nhi VPMRT được điều trị bằng PTNSMTKDL tại bệnh viện đa khoa Xanh Pôn từ tháng 1 năm 2018 tới tháng 5

feeding was 1.8 days. Early postoperative complications consisted of umbilical wound infection $5.4 \%$, persistent intra-abdominal infection/abscess $5 \%$ (no patient needed surgical revision). Postoperative cosmesis was excellent as all the patients virtually had no visible surgical scar. Conclusions: STAWoD is feasible in most cases of childhood PA, safe and with excellent cosmesis
\end{abstract} năm 2020. Trong PTNSMTKDL: chúng tôi đặt 1 Trocar $11 \mathrm{~mm}$ qua rốn và sử dụng optic $10 \mathrm{~mm}$ có kênh cho dụng cụ $5 \mathrm{~mm}$, ruột thửa được cắt bên ngoài hoặc trong ổ bụng, không đặt dẫn lưu. Kết quả: Có 306 bệnh nhân (BN) thuộc diện nghiên cứu, tuổi trung bình (TB) 7,9 tuổi. $80,4 \%$ BंN viêm phúc mac khu trú, $9,6 \%$ viêm phúc mạc toàn thể. $15 \%$ BN phải đặt thêm 2 trocar. Thời gian phẫu thuật TB 45,6 phút. Không có tai biến trong mổ. Thời gian nằm viện sau mổ trung bình (TB) 7,5 ngày. Thời gian TB phục hồi lưu thông tiêu hóa 1,8 ngày. Các biến chứng sớm sau mổ bao gồm nhiễm trùng vết mổ $5,4 \%$, nhiễm trùng/abscess tôn dư ổ bụng sau mổ $5 \%$ (không có BN nào phải mổ laii). Kết quả thẩm mỹ sau mổ rất tốt, các BN coi như không thấy sẹo mổ. Kết luận: PTNSMTKDL là khả thi ở đa số trường hợpVPMRT ở trẻ em, an toàn và có tính thẩm mỹ cao.

Tư khóa: Viêm phúc mạc ruột thừa, phẫu thuật nội soi một trocar, dấn lưu.

\section{SUMMARY}

SINGLE TROCAR LAPAROSCOPIC APPENDECTOMY WITHOUT DRAINAGE FOR PERFORATED APPENDICITIS IN CHILDREN

Objectives: To present our experience with single trocar laparoscopic appendectomy without drainage (STAWoD) for perforated appendicitis (PA) in children. Methods: Medical records of all children undergoing STAWoD for PA in St. Paul Hospital between January 2018 and May 2020 were reviewed. For STAWoD, we inserted a single $11 \mathrm{~mm}$ trocar through umbilicus and used $10 \mathrm{~mm}$ laparoscope with an engrafted working channel for $5 \mathrm{~mm}$ instruments; appendectomy was performed intra- or extracorporally; no abdominal drain was placed. Results: 306 patients were identified, with a median age of 7.9 years. $90.4 \%$ of the patients had localized and $9.6 \%-$ generalized peritonitis. Additional trocars were needed in $15 \%$ of the patients. The mean operative duration was 45.6 minutes. There were no intraoperative complications. The median postoperative hospital stay was 6.7 days. The median time to resuming of oral

*Bệnh viện đa khoa Xanh Pôn, Hà Nội Chịu trách nhiệm chính: Nguyễn Thị Hồng Vân Email: hongvanyd@gmail.com Ngày nhận bài: 14.10 .2020 Ngày phản biên khoa họ: 26.11.2020 Ngày duyệt bài: 8.12.2020
Keywords: Perforated appendicitis, single trocar laparocopic appendectomy, drain

\section{I. ĐĂTT VẤN ĐỀ}

Viêm phúc mạc ruột thừa (VPMRT) là trình trạng viêm phúc mạc cấp tính do viêm ruột thừa (VRT) có biến chứng vỡ, hay hoại tử gây ra với sự hiện diện của dịch mủ ở trong khoang phúc mạc. Ở trẻ em do đặc điểm tâm sinh lý rất khác người lớn, biểu hiện các triệu chứng lâm sàng thay đổi theo từng lứa tuổi, thăm khám khó hơn nên tỷ lệ VPMRT cao hơn so với người lớn, đặc biệt ở trẻ nhỏ. Cho đến nay phẫu thuật cấp cứu cắt ruột thừa vẫn là phương pháp điêuu trị qui chuẩn cho bệnh lý này. Các phương pháp mổ ngày càng được cải tiến theo xu hướng xâm lấn tối thiểu: từ phẫu thuật mở tới phẫu thuật nội soi (PTNS) 3 Trocar, phẫu thuật nội soi một Trocar qua rốn (PTNSMTQR)... Gần đây một số nghiên cứu đã cho thấy PTNSMTQR có thể xử lý được hâu hết các trường hợp VPMRT và có thể là lựa chọn ban đâu cho tất cả các thể viêm ruột thừa với tính an toàn, khả thi và không có sự khác biệt về biến chứng trong và sau mổ so với PTNS thông thường [7].

Một trong những biến chứng thường gặp sau mổ của VPMRT là abcess tôn dư ổ bụng. Nhiều phẫu thuật viên lựa chọn đặt dẫn lưu ổ bụng (DLOB) dự phòng để tránh biến chứng này. Dẫn lưu được đặt với mục đích loại bỏ dịch, máu, mủ sau mổ; ngoài ra còn giúp chẩn đoán sớm các biến chứng như chảy máu, rò tiêu hóa sau mổ(2). Tuy nhiên việc này cũng có một số bất lợi như: Tắc ống dẫn lưu, DLOB như là một dị vật có thể kích thích quá trình viêm của cơ thể, ngoài ra việc đặt dẫn lưu có thể làm tăng thời gian phẫu thuật, thời gian dùng thuốc kháng sinh, thuốc giảm đau, thời gian nhịn ăn, thời gian nằm viện cũng như tăng chi phí điều trị [3]. Do đó việc đă̆t DLOB cho phẫu thuật VPMRT cho đến nay vẩn còn nhiêu tranh cãi.

Tại Việt Nam PTNS điều trị VPMRT đã được áp dụng từ đâu những năm 2000 tại một số 
bệnh viện. Gần đây PTNSMTQR cũng đã được ứng dụng ở một số trung tâm trên cả nước đặc biệt là các trung tâm phẩu thuật nhi để điều trị viểm ruột thừa cấp. Nhưng hiện có rất ít trung tâm thực hiện phương pháp này để điều trị VPMRT cũng như việc đặt DLOB sau mổ đa phần vẫn được thực hiện thướng quy. Vì vậy chúng tôi tiến hành nghiên cứu phẫu thuật nội soi một trocar không đặt dẫn lưu (PTNSMTKDL) điều trị VPMRT ở trẻ em để đánh giá tính khả thi và hiệu quả của phương pháp này. Mục tiêu nghiên cứu. Báo cáo kết quả điều trị viêm phúc mạc ruột thừa (VPMRT) ở trẻ em bằng phẩu thuật nội soi một trocar không đặt dẫn lưu (PTNSMTKDL).

\section{II. ĐỐI TƯỢNG VÀ PHƯƠNG PHÁP NGHIÊN CỨU}

Chúng tôi hồi cứu các trường hợp bệnh nhi dưới 16 tuổi bị VPMRT được điểu trị bằng PTNSMTKDL tại bệnh viện đa khoa Xanh Pôn từ tháng 1 năm 2018 tới tháng 5 năm 2020.

Kỹ thuật mổ: Chúng tôi đặt 1 Trocar $11 \mathrm{~mm}$ qua rốn (sau khi đã đặt thiết bị bảo vệ vết mổ) và sử dụng optic $10 \mathrm{~mm}$ có kênh cho dụng cụ $5 \mathrm{~mm}$ (Hình 1). Nội soi đánh giá tình trạng ổ bụng, tìm ruột thừa và đánh giá tình trạng ruột thừa và khả năng di động của manh tràng từ đó để quyết định phương pháp cắt ruột thừa trong hay ngoài ổ bụng, có dùng hay không dùng kim hỗ trợ.

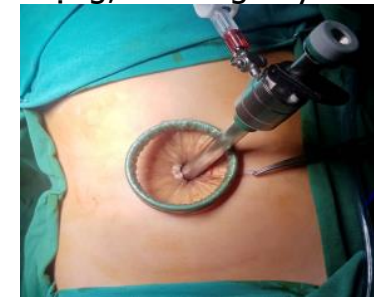

Hình 1: Đặt trocar qua

rốn

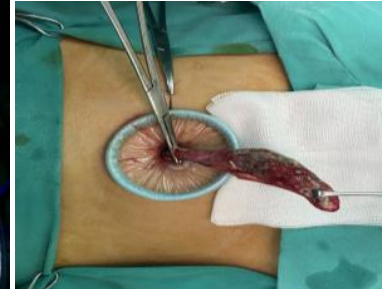

Hình 2: Cắt ruột thừa ngoài ổ bung
- Cắt ruột thừa trong ổ bụng: Chỉ định trong trường hợp manh tràng ít di động, mạc treo ruột thừa ngắn, dính, thành bụng dây không đưa được ruột thừa ra ngoài qua rốn. Dùng kim gây tê ngoài màng cứng $17 \mathrm{G}$ đưa xuyên qua thành bụng ở vùng man sườn phải vào ổ chỉ thép qua lòng kim vào ổ bụng tạo thành bụng, đưa thòng lọng. Dùng panh đưa RT qua thòng lọng và cố định đầu RT. Di chuyển đầu kim để bộc lộ mạc treo ruột thừa được thuận lợi. Dùng móc điện đơn cực phẫu tích cắt mạc treo RT. Sau đó, gốc ruột thừa được cặp bằng Hemolock $5 \mathrm{~mm}$, hoặc bằng nút chỉ thòng lọng Vicryl 2.0 qua nội soi. Cắt $\mathrm{RT}$ và đưa bệnh phẩm ra ngoài. Hút rửa sạch dịch mủ trong ổ bụng gứi dịch mủ cẫy khuẩn. Kiểm tra túi thừa Meckel. Không đặt dẫn lưu ổ bụng. Đóng vết mổ rốn 2 lớp.
- Cắt ruột thừa ngoài ổ bụng: Thực hiện ở những trường hợp ruột thừa và manh tràng $\mathrm{di}$ động tốt, ước tính có thể kéo tới vùng rốn. Dùng panh nội soi kẹp gốc hoặc ngọn ruột thừa ra ngoài ổ bụng qua vị trí đặt Trocar rốn (Hình 2). Cắt ruột thừa xuôi dòng hoặc ngược dòng, khâu buộc bốc ruột thừa bằng chỉ Vicryl 2.0, khâu buộc mạc treo ruột thừa bằng chỉ Vicryl 4.0 hoặc bằng đốt điện. Các trường hợp ban đầu mạc treo ruột thừa ngắn, manh trành kém di động nhưng sau khi giải phóng/cắt mạc treo ruột thừa và manh tràng đủ dài (kết hợp dùng kim xuyên qua da hỗ trợ nếu cần) mà đưa được qua rốn cũng có thể cắt ruột thừa ngoài ổ bụng tương tự như trên.

Sau mổ BN được truyền dịch, tiêm kháng sinh tĩnh mạch, dùng thuốc giảm đau. BN bắt đầu ăn lại khi không nôn, đánh hơi được. Chỉ định ra viện khi $\mathrm{BN}$ dùng hết liệu trình kháng sinh, ít nhất 3 ngày không còn triệu chứng.

Các chỉ tiêu đánh giá của nghiên cứu bao gồm: tuổi (năm), giới (nam, nữ), loại VPMRT (VPMTT, VPMKT), thời gian phẫu thuật (phút), phương pháp mố (cắt ruột thừa trong ổ bụng hay ngoài ổ bụng, có dùng kim hỗ trợ hay không), các biến chứng trong mổ, đặt thêm Trocar, chuyển mổ mở, Thời gian sử dụng thuốc giảm đau, thời gian phục hồi lưu thông tiêu hóa, thời gian nằm viện, các biến chứng sau mổ (nhiễm trùng vết mổ, nhiễm trùng ổ bụng dai dẳng, abcess tồn dư, tắc ruột) và kết quả thẩm mỹ.

Các số liệu nghiên cứu được xử lý trên máy vi tính theo chương trình phần mềm SPSS 20.0.

\section{KẾT QUẢ NGHIÊN CứU}

Trong thời gian nghiên cứu có 306 bệnh nhân $(\mathrm{BN})$, trong đó 145 trẻ nam và 161 trẻ nữ, tuổi trung bình (TB) 7,9 tuổi, BN nhỏ nhất 3 tuổi và lớn nhất 15 tuổi. Trong đó có 246 BN $(90,4 \%)$ VPMRT khu trú, VPMRT toàn thể có $60 \mathrm{BN}$ chiếm 9,6\%.

Phương pháp phẫu thuật: PTNSMTKDL thành công trong 85\% các trường hợp, $46 \mathrm{BN}$ phải chuyển mổ PTNS 3 Trocar (15\%), không có trường hợp nào phải chuyển mổ mở. Cắt ruột thừa ngoài ổ bụng chiếm đa số các trường hợp 241 BN (78,8\%), chỉ có 19 BN được ghi nhận cắt RT trong ổ bụng với PTNSMTQR, 46 BN cắt trong ổ bụng với PTNS 3 Trocar. Số BN có dùng kim hỗ trợ trong quá trình giải phóng mạc treo ruột thừa là $120 \mathrm{BN}(39,2 \%)$. Thời gian phẫu thuâat TB 45,6 phút (ngắn nhất 30 phút và dài nhất là 90 phút). Thời gian nằm viện sau mổ TB 7,5 ngày ( 5 ngày - 25 ngày), trong đó có $3 \mathrm{BN}$ nằm viện kéo dài 15 tới 25 ngày do nhiễm khuẩn huyết, tình trạng nhiễm trùng nặng từ ngay khi 
nhập viện. Thời gian TB phục hồi lưu thông tiêu hóa 1,8 ngày. Thời gian sử dụng thuốc giảm đau TB 1,6 ngày (1-3 ngày sau mổ), trong đó $93,1 \%$ $\mathrm{BN}$ chỉ phải dùng 2 ngày trở xuống. Không có tai biến trong mổ.

Các biến chứng sau mổ bao gồm: nhiễm trùng vết mổ 4,5\% (14 BN), các trường hợp này đều được điều trị bằng thay băng vết mổ thành công, không có khác biệt về thời gian sử dụng các thuốc kháng sinh và giảm đau so sới các bệnh nhân không có biến chứng này; nhiễm trùng/abscess tồn dư ổ bụng sau mổ 5,0\% (15 $\mathrm{BN}$ ), trong đó có $1 \mathrm{BN}$ cần đặt dẫn lưu dưới hướng dẫn siêu âm, các BN còn lại điêuu trị nội khoa bằng thuốc kháng sinh thành công. 1 trường hợp tắc ruột sau mổ 5 tháng được điều trị nội khoa thành công. Không có $B N$ nào phải mổ lại do các biến chứng sau mổ. Kết quả thẩm mỹ sau mổ rất tốt, kể cả các $B N$ bị nhiếm trùng vết mổ, coi như không thây sẹo mố (Hình 3).

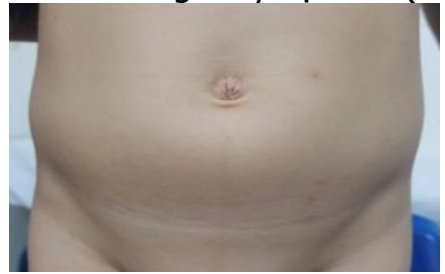

Hình 3: Thẩm mỹ vêt mổ sau 3 tháng

\section{BÀN LUÂN}

Phẫu thuật ít xâm lấn ngày càng được phát triển để đáp ứng nhu cầu ngày càng cao của bệnh nhân và gia đình người bệnh cũng như mong muốn của các bác sĩ đem lại kết quả tốt đẹp hơn trong điều trị. Phẫu thuật không để lại sẹo đặc biệt được chú ý với các bệnh nhân trẻ em, bởi vì các sẹo mổ có thể biến dạng theo quá trình lớn lên gây ảnh hưởng đến phát triển tâm lý của trẻ. PTNSMTQR trong nghiên cứu này, chúng tôi chỉ đă̆t 1 Trocar $11 \mathrm{~mm}$ qua vết mổ doc da rốn dài $10-11 \mathrm{~mm}$ (đường mổ hoàn toàn nẳm trong chu vi rốn nên sẹo mổ sẽ ẩn với các nếp lằn rốn tự nhiên) và sử dụng Optic nội soi có kênh cho dụng cụ $5 \mathrm{~mm}$ thao tác. Do đó chỉ cần 1 đường mổ nhỏ đã tiếp cận được điều trị, một mặt tránh được nguy cơ tổn thương các tang trong ổ bụng do đặt nhiều Trocar trong PTNS thong thường. Thêm nữa, vết mổ trong PTNSMTQR của chúng tôi nhỏ hơn so với PTNS một cổng, sử dụng cổng vào chuyên dụng (đường mổ dài $2-3 \mathrm{~cm}$ ).

Điểm quan trọng của phương pháp PTNSMTQR là xác định vị trí và mức độ di động của ruột thừa dưới sự hố trợ của dụng cụ nội soi 2 kênh qua rốn, đưa ruột thừa ra ngoài qua vị trí đăt Trocar và cắt ruôtt thừa như mổ mở. Phương pháp này hội tụ được những ưu điểm của cả phẫu thuật nội soi cũng như phẫu thuật mở, phẫu trường quan sát rộng và ít xâm lấn của PTNS cùng với chi phí thấp và dung cụ đơn giản của phẫu thuật mở. So với phẫu thuật nội soi thông thường, phương pháp này có vết mổ nhỏ, tính thẩm mỹ cao, thao tác đơn giản, dễ học, thời gian phẩu thuật ngắn [5]. PTNSMTQR khả thi hơn ở trẻ em so với người lớn vì khoảng cách từ rốn tới manh tràng ngắn hơn, manh tràng di động tốt hơn và thành bụng của bệnh nhi cũng đàn hồi tốt hơn người lớn. Những thuận lợi này cho phép đưa ruột thừa ra ngoài vết mổ ở rốn khá dễ dàng, với những trường hợp ruột thừa ít di động, mac treo ngắn, dính hay sau manh tràng có thể kéo vêt mổ về phía ruột thừa để bộc lộ dần ruột thừa ra ngoài ổ bụng [7]. Ngoài ra, chúng tôi còn sử dụng kim hố trợ để cố định ruôt thửa lên thành bunng và giải phóng mạc treo ruột thừa trong ổ bung trong những trường hợp khó, không thể đưa ruột thừa ra ngoài ổ bụng ngay được. Nhờ vậy mà tỷ lệ thành công của phương pháp này khá cao, chỉ có $15 \%$ phải chuyển mổ PTNS thông thường 3 trocar và không có trường hợp nào chuyển mổ mở. Chúng tôi nhận thấy kỹ thuât mổ này khá đơn giản và dễ học, thời gian phấu thuật giảm dần theo thời gian và sự thành thục của phẫu thuật viên.

Bảng 1. So sánh kết quả PTNSMTKDL của chúng tôi với các kĩ thuật khác trong điều trị VPMRT

\begin{tabular}{|c|c|c|c|c|c|c|c|c|c|}
\hline $\begin{array}{c}\text { Tác giả /năm } \\
\text { công bố }\end{array}$ & PP mổ & $\mathrm{n}$ & $\begin{array}{c}\text { Tg phâu } \\
\text { thuât } \\
\text { (phút) }\end{array}$ & $\begin{array}{c}\text { Tg nằm } \\
\text { viện } \\
\text { (ngày) }\end{array}$ & $\begin{array}{c}\text { Đă̆t thêm } \\
\text { Trocar } \\
\text { (\%) }\end{array}$ & $\begin{array}{c}\text { Chuyế } \\
\text { nMố } \\
\text { mở }\end{array}$ & $\begin{array}{c}\text { Nhiêm } \\
\text { trùng } \\
\text { vết mổ }\end{array}$ & $\begin{array}{c}\text { Abcess } \\
\text { tôn dư }\end{array}$ & $\begin{array}{c}\text { Tắc } \\
\text { ruột }\end{array}$ \\
\hline Sara H-M 2017[7] & 1 Trocar & 136 & $44,1 \pm 13.6$ & $7 \pm 3$ & & & $11 \%$ & $11,8 \%$ & $2,2 \%$ \\
\hline Paul A.K, 2016[5] & 1 Trocar & 29 & $60(24-227)$ & $2,5(1,10)$ & $31 \%$ & & $10 \%$ & & \\
\hline Hye K C, 2013[6] & 3 Trocar & 99 & $114.2 \pm 34.0$ & $10.1 \pm 3.5$ & & & $4 \%$ & $3 \%$ & $0 \%$ \\
\hline Esmaeel T,2008(4) & 3 Trocar & 68 & 72,6 & 5 & & & $1,5 \%$ & $4,4 \%$ & \\
\hline TN Sơn, 2011 [1] & 3 Trocar & 260 & $74 \pm 22.6$ & $6 \pm 2$ & & & $1,4 \%$ & $3, .3 \%$ & $5,4 \%$ \\
\hline Yasumitsu H,2018(8) & SILA & 29 & 83,3 & 7,6 & $10,3 \%$ & 0 & $13,8 \%$ & & \\
\hline Chúng tôi 2020 & 1 Trocar & 306 & 45,6 & 7,5 & $15 \%$ & 0 & $4,5 \%$ & $5,0 \%$ & $0,3 \%$ \\
\hline
\end{tabular}


Thời gian mổ trung vị của chúng tôi là 45,6 phút, tương tự với báo cáo của Sara HernandezMartin [7] ngẳn hơn trong báo cáo của Paul $\mathrm{A}$. Karam 60 phút với cùng phương pháp mổ [5]. So sánh với các phương pháp phẩu thuật khác như phẫu thuật nội soi 3 Trocar hay phẫu thuật nội soi một đường rạch qua rốn với port chuyển dụng, thời gian phẫu thuật trung bình của chúng tôi ngắn hơn $[1,4,6,8]$ (Bảng 1$)$.

Trong nghiên cứu của chúng tôi, tỷ lệ nhiễm trùng/ abcess tồn dư sau PTNSMTKDL là 5.0\%, thấp hơn so với các tác giả khác cùng phương pháp mổ nhưng còn cao hơn một chút so với các phương pháp 3 Trocar hay SILA (Bảng 1).

Tỷ lệ nhiếm trùng vết mổ của chúng tôi là $4,5 \%$, thấp hơn các tác giả cùng kỹ thuật và SILA, cao hơn nhóm 3 Trocar (Bảng 1). Các BN bị nhiễm trùng vết mổ đều được điều trị khỏi bằng chăm sóc, thay băng tại chố, không cần khâu da thì 2. Ngay cả đối với các BN nhiễm trùng vết mổ rốn, kết quả thẩm mỹ sau 3 tháng khám lại đều rất tốt, vết mổ liền tốt trong phạm vi rốn và khó nhận thây sẹo mổ.

Trong nhóm nghiên cứu của chúng tôi chỉ có 1 BN phải tái nhập viện vì tắc ruột sau mổ 5 tháng, tuy nhiên $\mathrm{BN}$ này cũng được điều trị nội khoa thành công và không phải mổ lại. So sánh với kết quả nghiên cứu của Sara Hernandez-Martin [7] biến chứng tắc ruột 2.2\%, TN Sơn [8] 5,4\%.

Mặc dù đặt dẫn lưu ổ bụng là một trong những phương pháp được sử dụng từ lâu. Trong suốt 2 thế kỉ qua, các phẫu thuật viên sử dụng dẫn lưu với mục đích dẫn lưu dịch còn lại hoặc hình thành mới và phát hiện sớm các biến chứng sau mổ. Tuy nhiên nhiều nghiên cứu gần đây cho thấy việc đặt dẫn lưu ổ bụng sau mổ viêm phúc mạc ruột thừa ở cả trẻ em và người lớn đều khồng giúp giảm các biến chứng sau mổ như abcess tồn dư hay nhiễm trùng vết mổ [3]. Các nghiên cứu so sánh việc đặt dẫn lưu và không đặt trong điều trị VPMRT cho các kết quả sau: theo Ahmed Kamel Abdulhamid so sánh 2 nhóm đặt dẫn lưu (114 BN) và nhóm không đặt dẫn lưu (113 BN) cho thấy nhóm đặt DLOB $36,8 \% \mathrm{BN}$ bị nhiễm trùng vết mổ, Abcess tồn dư là $43,9 \%$; nhóm không đặt DLOB $33.6 \%$ bị NT vết mổ, abcess tồn dư $46,9 \%$, sự khác biệt không có ý nghĩa thống kê. Tuy nhiên thời gian nằm viện giữa 2 nhóm có sự khác biệt đáng kể: nhóm không DL là 2.12 ngày, trong khi nhóm còn lại thời gian nằm viện dài gấp đôi 4,99 ngày [2]. Tương tự, B. Aneiros Castro cũng ghi nhận không có sự khác biệt ý nghĩa về các biến chứng (Abcess sau mổ nhiễm trùng vết mổ; tắc ruột sau mổ) giữa 2 nhóm. Thời gian nằm viện trung bình của nhóm đặt dẫn lưu trong nghiên cứu này cũng dài hơn có ý nghĩa so với nhóm không đặt DLOB [3].

Một vài giả thuyết giải thích cho việc thất bại của dẫn lưu ổ bụng trong ngăn ngừa các biển chứng sau mổ được đưa ra. Thứ nhất dẫn lưu có thể bị tắc bởi máu cuc, mủ, giả mạc, sợi tơ huyết. Thứ hai, đầu dẩn lưu được đặt ở một vị trí cố định có thể không dẫn lưu được hết dịch trong toàn bộ khoang bụng. Thêm vào đó, dẫn lưu ổ bụng làm thông thương khoang phúc mạc với môi trường bên ngoài có thể làm tăng nhiếm trùng vết mố. Dẫn lưu bản thân nó cũng là dị vật gây kích thích các phản ứng viêm của cơ thể. Hiếm hơn, một số trường hợp biến chứng của đặt dẫn lưu đã được báo cáo là đặt dẫn lưu xuyên thành ruột hoặc gây rò manh tràng sau mổ. Ngoài ra, nhóm đặt dẫn lưu có thời gian nằm viện dài hơn do thời gian cần thiết cho quá trình theo dõi dẫn lưu, rút dẫn lưu, đau tại vị trí dẫn lưu cũng như nguy cơ nhiễm trùng tăng làm chậm thời gian ăn lại và hồi phục chung của BN [2].

Nghiên cứu của chúng tôi còn tồn tại một số hạn chế như nghiên cứu hồi cứu, không có nhóm chứng ngẫu nhiên. Mặc dù vậy, nghiên cứu này trên số lượng khá lớn bệnh nhân VPMRT với kết quả theo dõi dọc đã cho thấy PTNSMTKDL có tính khả thi, an toàn và thẩm mỹ cao.

\section{KẾT LUẬN}

PTNSMTKDL có thể thực hiện được thành công trên đại đa số các trường hợp VPMRT ở trẻ em. Đây là phương pháp an toàn và có tính thẩm mỹ cao.

\section{TÀl LIỆ THAM KHẢO}

1. Trần Ngọc Sơn, Vũ Mạnh Hoàn, Nguyễn Thanh Liêm (2011). Điều trị viêm ruột thữa thửng ở trẻ em: So sánh giữa phẫu thuật nội soi và mổ mở. Tạp chí Y hoc TP Hồ Chí Minh. 15:43-47.

2. Abdulhamid AK, Sarker SJ (2018). Is abdominal drainage after open emergency appendectomy for complicated appendicitis beneficial or waste of money? A single centre retrospective cohort study. Annals of Medicine and Surgery.36: 168-172.

3. B. Aneiros Castro, I. Cano, A. García, P. Yuste, E. Ferrero, A. Gómez (2018). Abdominal Drainage After Laparoscopic Appendectomy in Children: An Endless Controversy? Scand J Surg. 107(3):197-200.

4. Esmaeel Taqi, Sulaiman Al Hadher, Jon Ryckman (2008) Outcome of laparoscopic appendectomy for perforated appendicitis in children. Journal of Pediatric Surgery. 43(5):893-895.

5. Paul A. Karam, Arathi Mohan, Martin R. Buta, Federico G. Seifarth (2016). Comparison 
of Transumbilical Laparoscopically Assisted Appendectomy to Conventional Laparoscopic Appendectomy in Children: Surgical Laparoscopy, Endoscopy \& Percutaneous Techniques. 26(6):508-512.

6. Pisanu A, Porceddu G, Reccia I, Saba A, Uccheddu A (2013). Meta-analysis of studies comparing single-incision laparoscopic appendectomy and conventional multiport laparoscopic appendectomy. Journal of Surgical Research. 183(2):e49-e59.

7. Sara Hernandez-Martin, Lidia Ayuso, Ada
Yessenia Molina, Pison J, Miguel Angel Martinez-Bermejo, Alberto Perez-Martine (2017). Transumbilical laparoscopic-assisted appendectomy in children: is it worth it? Surg Endosc. 31(12):5372-5380.

8. Yasumitsu Hirano, Yasuhiro Ishiyama, Mari Shimada, Chikashi Hiranuma, Yasuo Hashizume, Keizo Taniguchi (2018). Comparison of Outcomes of Single-Incision Laparoscopic and Open Appendectomy in Management of Uncomplicated and Complicated Appendicitis. Indian J Surg;80(5):442-446.

\section{ĐĂC ĐIỂM HÌNH ẢNH NộI SOI PHẾ QUẢN VÀ NGUYÊN NHÂN GÂY VIÊM PHỔI BÊNH VIỆN CỦA BỆNH NHÂN THỞ MÁY ĐIỀU TRI TẠI KHOA HỒI SỨC TÍCH CỰC - BÊ̂NH VIỆN HỮU NGHI!}

\section{TÓM TẮT}

Mục tiêu: Mô tả đặc điểm hình ảnh nội soi phế quản về tổn thương niểm mac và lượng dich tiết của bệnh nhân Viêm phổi bệnh viện có thở máy tại khoa HSTC - CĐ bênh viện Hữu Nghị.Đặc điểm Vi khuẩn gây Viêm phổi bệnh viện (VPBV) và tình trạng đề kháng với các kháng sinh thường dùng của các vi khuẩn phân lập được. Phương pháp nghiên cứu: Nghiên cứu mố tả cắt ngang 39 bênh nhân thở máy tại khoa Hồi sức tích cực và chống độc bệnh viện Hữu Nighi từ 2/2019 đến 10/2020, được chẩn đoán Viêm phổi bệnh viện, có chỉ định Nội soi phế quản, nuôi cấy dịch phế quản cho kết quả dương tính và được làm kháng sinh đồ. Kết quả: Tổng số 39 bệnh nhân thở máy đủ tiêu chuẩn chẩn đoán VPBV, hình ảnh nội soi phế quản cho thấy đặc điểm tổn thương niêm mạc dang thâm nhiếm có tỷ lệ cao nhất chiếm 48,2\%, dịch tiết đờm loãng và đờm đặc có tỷ lệ tương đương, cùng là $38 \%$, còn lại là hình ảnh viêm mủ phế quản. Kết quả nuối cấy dich phế quản và kháng sinh đồ cho thấy nguyên nhân chủ yếu là vi khuẩn Gram âm chiếm $97 \%$, trong đó cao nhiều nhất là Klebsiella pneumoniae chiếm tỷ lệ cao nhất với $41 \%$, tiếp đó là Pseu. Aeruginosa với tỷ lê $36 \%$. Gram dương là vi khuẩn cơ hội chiếm $3 \%$, không thấy Tụ câu vàng. Acinetobacter. Baumannii chiếm tỷ lê thấp hơn tuy nhiên đề kháng kháng sinh mạnh hớn. Trong các Vi khuẩn Gram âm thường găp, tỷ lệ đề kháng rất cao với kháng sinh nhóm Cefalosphorin và Quinolon (> $70 \%)$, để kháng thấp hơn với nhóm Carbapenem, Piperacillin/Tazobactam và Cefoperazone/Sulbactam. Kết luân: Tổn thương niêm mạc phế quản và tính chất dịch tiết không có đô tương quan, tuy nhiên phân nào phản ánh mức độ tổn thương phổi, giúp thay đổi

*Bênh viện Hữu Nghị

Chịu trách nhiệm chính: Lê Quang Phương

Email: drphuongle.icu@gmail.com

Ngày nhận bài: 15.10 .2020

Ngày phản biên khoa hoc: 30.11 .2020

Ngày duyệt bài: 7.12.2020
Lê Quang Phương*, Nguyễn Minh Lực*

thái độ điều trị. Nguyên nhân gây VPBV chủ yếu là vi khuẩn Gram Âm. Các VK Gram Âm thường gặp đề kháng cao với nhiều loại kháng sinh hay dùng, đặc biệt là nguyên nhóm Quinolon và Cefalosphorin, còn nhạy cảm với Carbapenem, Piperacillin/Tazobactam và Cefoperazone/Sulbactam

Tư khóa: Nội soi phế quản, Viêm phổi bệnh viện (VPBV), Vi khuẩn Gram âm, Vi khuẩn Gram dương.

\section{SUMMARY \\ CHARACTERISTIC OF BRONCHOSCOPY IMAGES AND MICROBIOLOGICAL CAUSES OF HOSPITAL ACQUIRED PNEUMONIA IN ICU DEPARTMENT FRIENDSHIP HOSPITAL}

Objectives: Describe the characteristics of bronchoscopy images of mucosal lesions and bronchial secretions of patients with Hospital AcquiredPneumonia (HAP) with ventilatior at the ICU Department - Huu Nghi Hospital. Characteristics Bacteria cause HAP and Status resistance to commonly used antibiotics of isolated bacteria. Methods: A cross-sectional studyof 39 ventilated patients at Huu Nghi hospital's ICU department, diagnosed HAP, with indications Bronchoscopy, bronchial fluid culture showed positive results and made Antibiotic Resistance. Result: A total of 39 ventilated patients qualified for diagnosis HAP, bronchoscopy images showed the characteristics of infiltrated mucosal lesions with the highest rate accounting for $48.2 \%$, dilute sputum secretions and thick sputum, equivalent rates, the same $38 \%$, the rest is bronchitis purulent inflammation. The results of bronchial fluids and antibiotic culture showed that the main cause was Gram-negative bacteria, accounting for $97 \%$, of which the highest rate was Klebsiella pneumoniae with $41 \%$, followed by Pseu. Aeruginosa ratio $36 \%$. Gram-positive bacteria accounted for 3\%, was opportunistic bacteria. Staphylococcus aureus was not found.Acinetobacter. Baumannii accounts for a lower proportion but more resistant to antibiotics. In common Gram-negative bacteria, the rate of 